Bettina Bahn-Walkowiak, Raimund Bleischwitz, Martin

Distelkamp, Mark Meyer

\title{
Taxing construction minerals: a contribution to a resource-efficient Europe
}

Originally published as:

Bettina Bahn-Walkowiak, Raimund Bleischwitz, Martin Distelkamp, Mark Meyer (2012):

Taxing construction minerals: a contribution to a resource-efficient Europe In: Mineral Economics, 25, 1, 29-43 
Bettina Bahn-Walkowiak ${ }^{a^{*}}$, Raimund Bleischwitz ${ }^{a}$, Martin Distelkamp ${ }^{\text {b }}$, Mark Meyer ${ }^{\text {b }}$

\title{
Taxing construction minerals: a contribution to a resource-efficient Europe
}

\author{
a Wuppertal Institute for Climate, Environment, Energy, Germany \\ b GWS Institute of Economic Structures Research, Osnabrück, Germany \\ * Corresponding author: Bettina Bahn-Walkowiak, Wuppertal Institute for Climate, Environment, \\ Energy, Doeppersberg 19, 42349 Wuppertal, Germany \\ E-mail: bettina.bahn-walkowiak@wupperinst.org
}

Phone: +49-(0)202-2492-276

Fax: +49-(0)202-2492-250 


\title{
Taxing construction minerals: a contribution to a resource-efficient Europe
}

\begin{abstract}
This paper focuses on market incentives by the introduction of a construction minerals tax as an example of a resource tax. Currently, various European countries levy taxes or duties on primary construction materials, but a harmonisation of the taxation is not planned. Provided the tax rate has a perceptible price effect, the taxation of a resource can foster a demand management or the reduction of the raw material consumption and the governance of side and secondary effects. A construction minerals tax can target the stimulation of demand for secondary raw materials and recycled products, and - because the reuse of construction and demolition waste has technical limits - a stronger emphasis on the conservation of buildings and infrastructures. This has positive effects on the environment and the innovation efforts and it helps to internalise externalities. Germany, used as a case study in this paper, does not raise any taxes on other raw materials than energy sources at the federal level. For this reason, potential impacts of the introduction of a construction minerals tax will be explored and the results of a simulation will be provided.
\end{abstract}

Keywords: environmental taxes, resource management, economic incentives for innovation and efficiency, simulation

\section{JEL Classification}

- H23 (externalities; environmental taxes and subsidies)

- O32 (management of technological innovation and R\&D)

- Q32 (exhaustible resources and economic development)

- Q38 (government policy)

- E27 (forecasting and simulation: models and applications) 


\section{Content}

1 Why taxing construction minerals? 3

1.1 The proportion of environmental and resources taxes in Europe ___ 3

1.2 Impacts of sand, gravel, crushed rock and limestone extraction and use __ 4

1.3 Sector trends of extraction

2 Conception of a construction minerals tax

2.1 Targets, mechanisms and expected impacts __ 10

2.1.1 Increase of input quota of recycling and secondary materials ___ 12

2.1.2 Barriers and trade-offs ___ 14

2.2 Experiences and diffusion of minerals extraction taxes in Europe $\_15$

3 Case study: A primary construction minerals tax in Germany _ 18

3.1 Federal excise tax on the extraction and the import of primary construction $\begin{array}{ll}\text { minerals } & 18\end{array}$

3.2 Reform of the current land use and extraction charge ___ 19

3.3 Results of a simulation study ___ 21

4 Conclusions

5 References_ 22 


\section{$1 \quad$ Why taxing construction minerals?}

\subsection{The proportion of environmental and resources taxes in Europe}

In industrialised countries, housing, mobility, food and electrical appliances typically account for over $70 \%$ of the impacts of household consumption (UNEP 2010) while $15-30 \%$ of the key environmental pressures from European consumption stem from construction and housing alone, which thus belong to the priority product chains (Moll and Watson 2009).

In order to respond to environmental impacts and pressures and generate revenues, European countries collect environmental taxes within the three categories energy, transport, pollution and resources. The weighted average of the revenue by environmental taxes in EU-27, however, constituted only $2.4 \%$ of the Gross Domestic Product (GDP) in 2008. While Sweden, Austria, Germany and Estonia obtain more than $55 \%$ of their total taxes from labour taxes (Eurostat/EC 2010), taxes on resources and pollution are still marginal. Moreover, environmental taxes have actually been falling again. They only amount to $5 \%$ of the total environmental taxes, accounting to only $0.1 \%$ of GDP, while the overwhelming part of environmental taxes is usually generated by energy and transport taxes (Eurostat 2010). Figure 1 below compares the allocation of environmental taxes in the EU, Germany, France and Denmark. Denmark has by far the highest share of taxes on pollution/resource (31\%), while Germany has the lowest percentage (2\%).

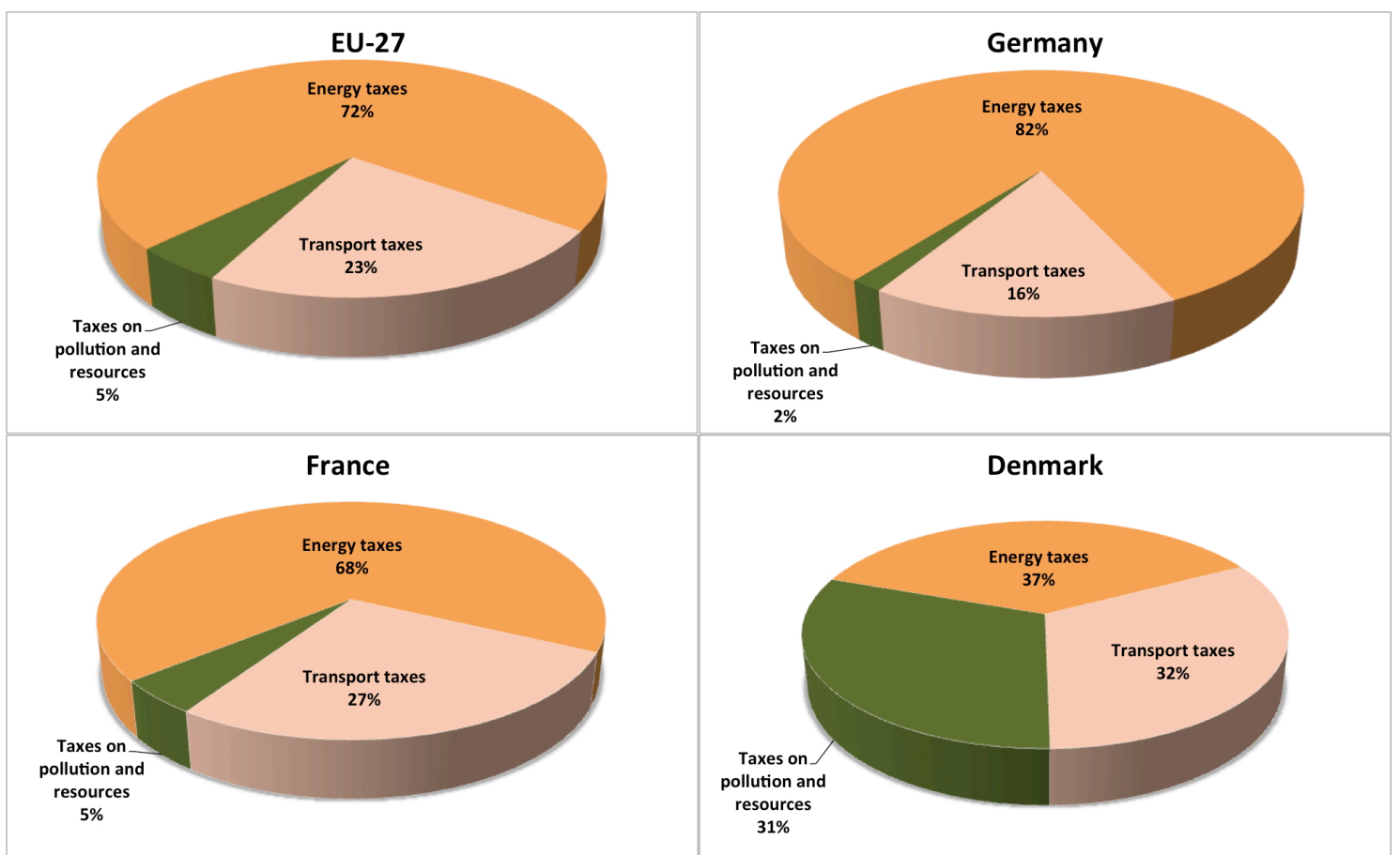

Figure 1: Distribution of environmental taxes in the EU in 2008; Source: Eurostat 2011, own compilation

Economic instruments have an important role to play in environmental governance and policy and taxes on raw materials are increasingly being discussed as a means towards a reorientation from labour-related taxes to taxes beyond the existing basis of energy and transport (EC 2011c). Occasionally, a general resource or material input tax is proposed, which is difficult to realise presently because imports and international trade is involved and the national and international databases are not yet mature to monitor the 
exact material flows. In order to move forward and widen the scope for environmental taxes, a tax on the most material-intensive but, in terms of trade and flows, largely self-sufficient sector and technology field is proposed in the following $-\mathrm{a}$ tax on primary construction minerals.

\subsection{Impacts of sand, gravel, crushed rock and limestone extraction and use}

From the beginning of the value chain the mining and use of construction materials such as sand, gravel, crushed stone and limestone has direct and indirect environmental impacts and consequences. The extraction process causes non-reversible landscape alterations and is associated with the loss of agricultural land and other land use options. In addition, the groundwater levels and the filtration of the rocks are affected. It is often argued that the restoration of the gravel and sand mining areas compensates the surrounding scenery by leading to new valuable land use and thus positively contributes to biodiversity. Due to geological conditions, however, excavations are carried out more frequently in a very concentrated manner (e.g. in river valleys such as the Lower Rhine area in Germany). Recultivation usually also depends on state laws and enforcement because a common legal framework for non-energy mineral resources recultivation is no Europe-wide mandatory part of the approval procedures for excavations (Seht 2010).

After extraction further impacts arise during processing and use of construction minerals. Energy- and emission-intensive manufacturing processes of concrete, cement, glass and ceramic products using aggregates as a base material, and the contribution of the material to an unbroken high level of land use and sealing by the construction of roads and buildings have to be mentioned from a life-cycle perspective. Other consequences are the high proportion of stones in the transport volume of heavy goods vehicles (up to 45\%) (European Environment Agency 2010; Bleischwitz and Bahn-Walkowiak 2007; Sciullo and Smihily 2006). Figure 2 illustrates the environmental impacts of the single supply chain stages while resource conservation, supply scarcities and interactions with other resources may also be motives for the search for a suitable policy. 
Resource i n p u t

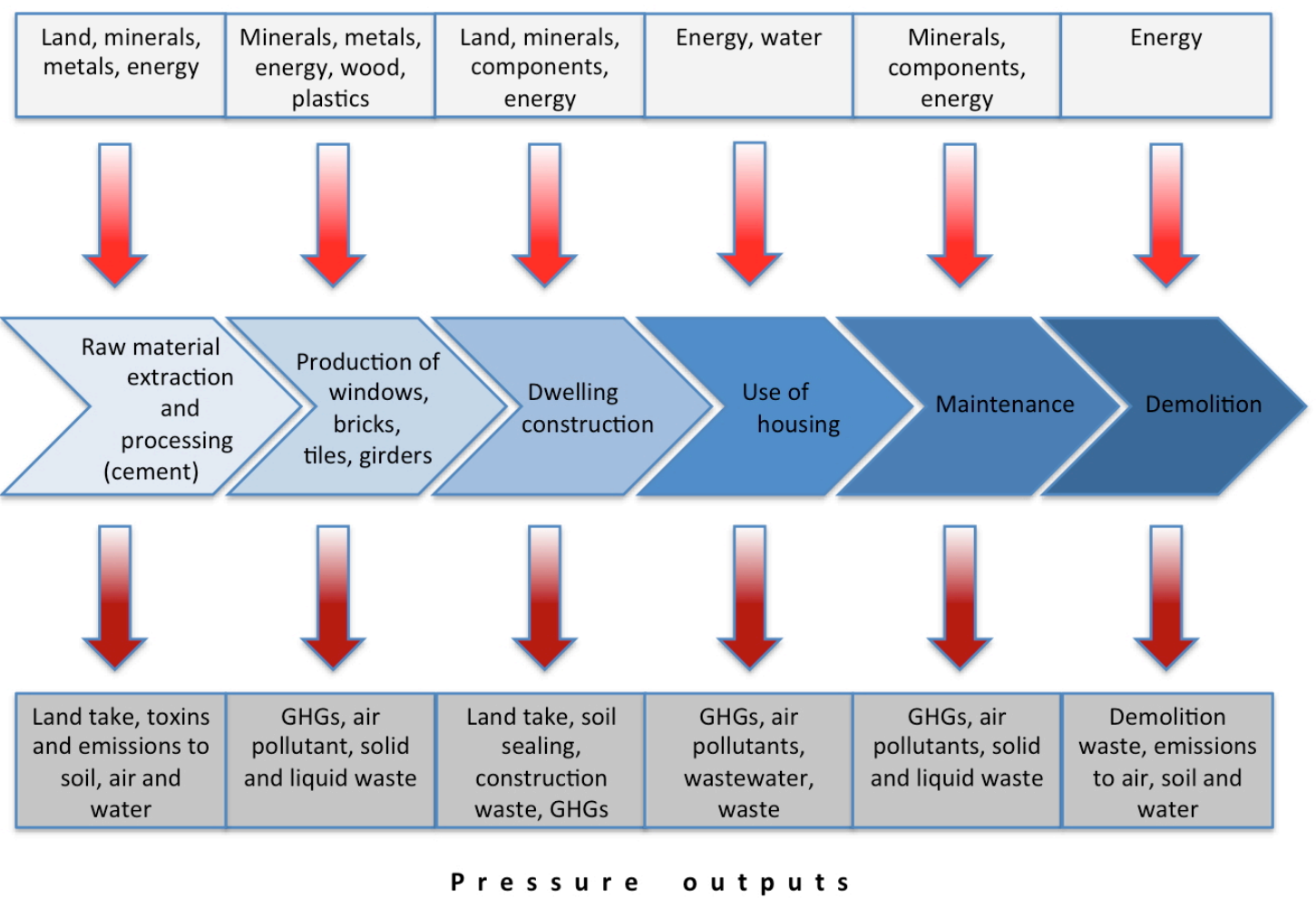

Figure 2: The construction and housing value chain and its environmental impacts; after European Environment Agency 2010

The input rate of recycling and secondary materials varies considerably within Europe (for instance, Germany, 9\% according to Federal Environment Agency 2009; UK, 25\% according to Resources Action Programme 2011). Recycling construction minerals include, for example, recycled concrete or separated construction and demolition wastes crushed to a certain particle size (such as concrete, asphalt or mixed demolition granules). Secondary materials are generally by-products of other industrial processes that do not necessarily belong to the construction sector such as fuel ashes and slags from blast furnaces or incinerators. Largely, those processes are rather a down-cycling of materials and scarcely at high quality (Knappe 2009). The sector shows large unused potentials.

As regards the tonnage of extracted resources the construction minerals sub-sector is the largest in Europe (NACE codes CB14.1 and CB14.21). Germany, France, Italy and Spain are the four main producers of construction minerals in Europe with changing rankings among them. Together, they produce more than 1.2 billion tonnes/year of a total of approximately 3 billion tonnes in the EU (British Geological Survey 2011; UEPG 2011). Most of the European countries are self-sufficient regarding their domestic demand of construction minerals.

The resources to be covered by a construction minerals tax are natural aggregates such as sand, gravel and crushed stone and limestone, sometimes also termed as primary construction minerals. According to the British Geological Survey, which carries out the annual collection of data of the raw material excavation in Europe, the following rocks and applications are counted to the construction minerals (British Geological Survey 2011) (Table1). 
Table 1: Construction minerals and their principal uses

\begin{tabular}{|l|l|}
\hline Construction minerals & Principal uses \\
\hline $\begin{array}{l}\text { Aggregates, natural sand and gravel } \\
\text { Crushed rock (limestone, sandstone, igneous rock, etc.) }\end{array}$ & $\begin{array}{l}\text { Concrete, building sand and fill } \\
\text { Road stone, fill, concrete }\end{array}$ \\
\hline Clay and shale & Bricks, pipes, tiles and cement manufacture \\
\hline Gypsum & Plaster, Plasterboard and cement \\
\hline Limestone and dolomite & $\begin{array}{l}\text { Crushed rock aggregate, cement, other industrial and } \\
\text { agricultural uses }\end{array}$ \\
\hline Building stone (dimension stone) & $\begin{array}{l}\text { Any competent rock-type that may be uses in the form } \\
\text { of shaped and/or sized blocks for either structural or } \\
\text { decorative purposes (also roofing stone and slate) }\end{array}$ \\
\hline
\end{tabular}

Source: British Geological Survey 2011, p. iv

In some sectors, the key raw material component is sand, e.g. in civil engineering, road construction and earthworks. As a construction mineral sand is essential for producing building materials like concrete and mortar. Since it is easy to form, it is also used for the interior and facade decoration of buildings. Besides sand gravel is the main mass raw material and it is extracted from gravel pits. Gravel is also an essential raw material for the construction industry and it is predominantly used as an additive for concrete. Other applications are as fill material for earthworks and as ballast in railway construction. Crushed rock has different grain sizes and is used - depending on the size of stone - for base layers of roads or with binders such as bitumen in asphalt concrete or with cement and water as concrete or cement-bound base. Crushed rock is also used as a frost protection layer beneath the paved roads and also as ballast for track beds. Limestone is a sedimentary rock and has also great economic importance as a raw material for the construction industry, particularly ground with other materials and fired as cement, which constitutes an important binding agent in concrete.

All those rocks belong to the inorganic materials; organic materials are, for example, wood and cellulose. Germany predominantly uses inorganic materials. The inclusion of biotic resources in a tax is worth to be considered. Other rock types (such as clay, marl, shale, etc.) could also be included in a tax as relevant materials for the construction industry and for reasons of equal treatment. In 2008, gravel and building sand were with 249 million tonnes by far the largest share of raw materials gained in Germany, 218 million tonnes natural stones and 50 million tonnes limestone and clay bricks have to be added (Bundesverband der Deutschen Kies- und Sandindustrie, Bundesverband Mineralische Rohstoffe 2009). Over an assumed life span of 80 years, the consumption of sand and gravel of a human being is 245 tonnes, plus 215 tonnes natural stones and 70 tonnes of limestone (Bundesanstalt für Geowissenschaften und Rohstoffe 2010). A part of these materials can be recovered and recycled; however, the potentials in this area are not fully exploited.

\subsection{Sector trends of extraction}

Based on the absolute weight of the extracted quantities of sand, gravel, crushed stone and limestone, the mineral sector is the most resource-intensive sector in Europe (see Figure 3); this applies to the Direct Material Input, the Domestic Material Consumption and the Domestic Extraction Used (DEU). 37\% of the DEU in EU-27 in 2007 is sand and gravel, followed by $23 \%$ of other non-metallic minerals. 


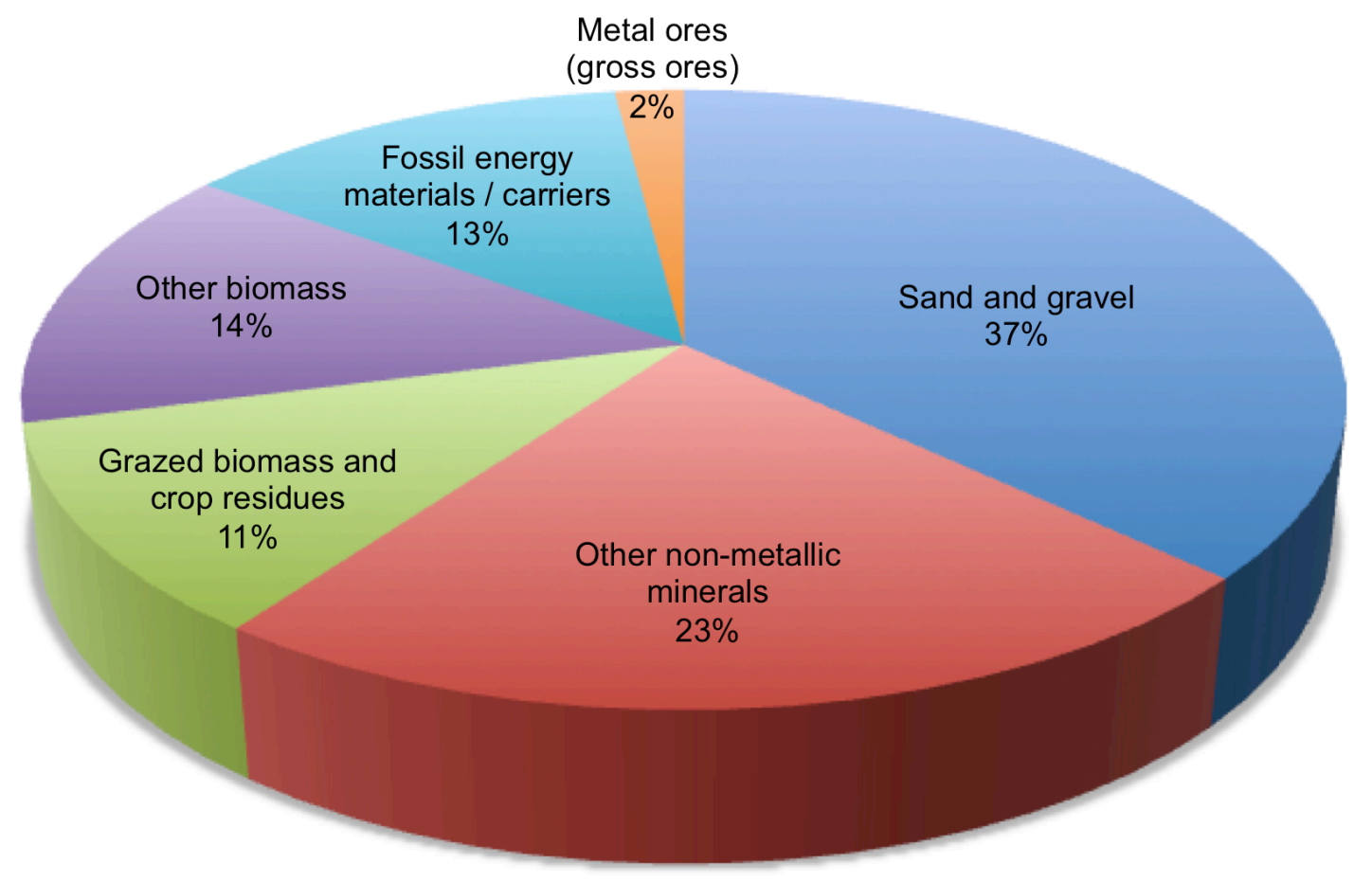

Figure 3: Domestic extraction used (DEU) by materials, EU-27, 2007 (in \% of total); Eurostat 2011

The time series of the British Geological Survey show that primary aggregates (sand, gravel and crushed rock) as part of the construction minerals are being extracted on a remaining high level. The economic situation is highly dependent on the construction industry resulting in up- and downturns. In particular, the recession in 2008-2009 has contributed to a slump of the construction industry and hence to a fall-off of construction minerals extraction (see Figure 4). 


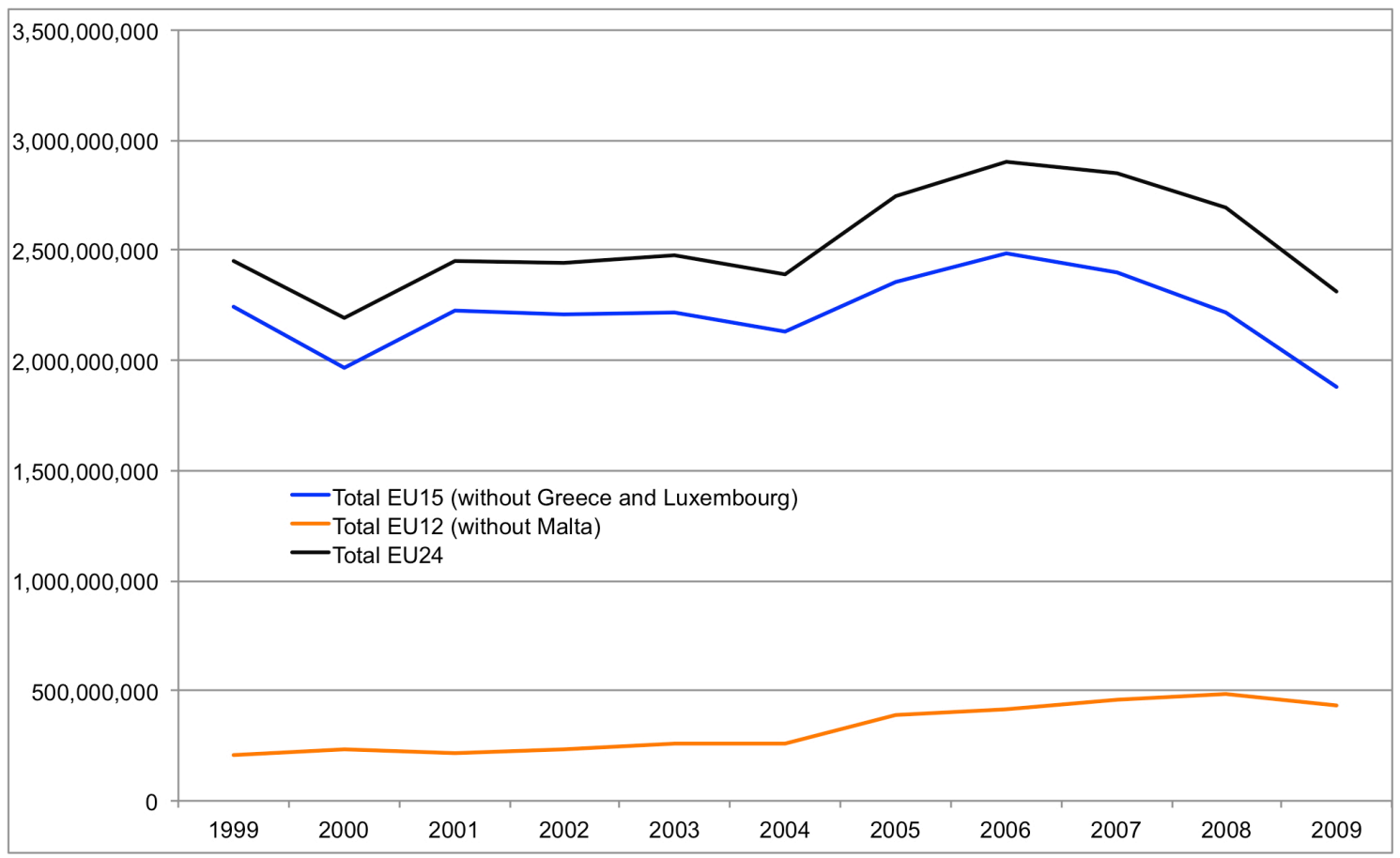

Figure 4: Domestic Extraction of construction minerals in the years 1999 to 2009; own calculations on the basis of British Geological Survey $(2005,2010,2011)^{1}$

The figure also shows that especially the New Member States in Europe (EU-12) who joined the EU in 2004 and 2007 have observed a considerable growth since that time by doubling their minerals extraction (similar results European Environment Agency 2010). For the years 2004 to 2006, there were also notable rates of growth in the EU-15.

The per capita production of the construction minerals (see Figure 5) illustrates how important cyclical changes in this sector are. The average per capita use of construction minerals in EU-15 was around 8.4 tonnes/capita in the years 1999 to 2004, grew up to 10.2 until 2007, came down to its former level in 2008 and only fell in 2009 to 6.4 tonnes/capita. The curve for the EU-12 per capita extraction shows a steady increase from 2.8 to 7.3 tonnes/capita from 1999 to 2008 and a downturn to 5.9 tonnes/capita in 2009. It is questionable that it can be described as a downward trend. In fact, it has to be assumed that at both ends of the time series, figures may be subject to lack of data and thus appear to be lower.

1 EU-12: Bulgaria, Cyprus, Czech Republic, Estonia, Hungary, Latvia, Lithuania, Malta, Poland, Romania, Slovakia, Slovenia

EU-15: Austria, Belgium, Denmark, Finland, France, Germany, Greece, Ireland, Italy, Luxembourg, Netherlands, Portugal, Spain, Sweden, UK 


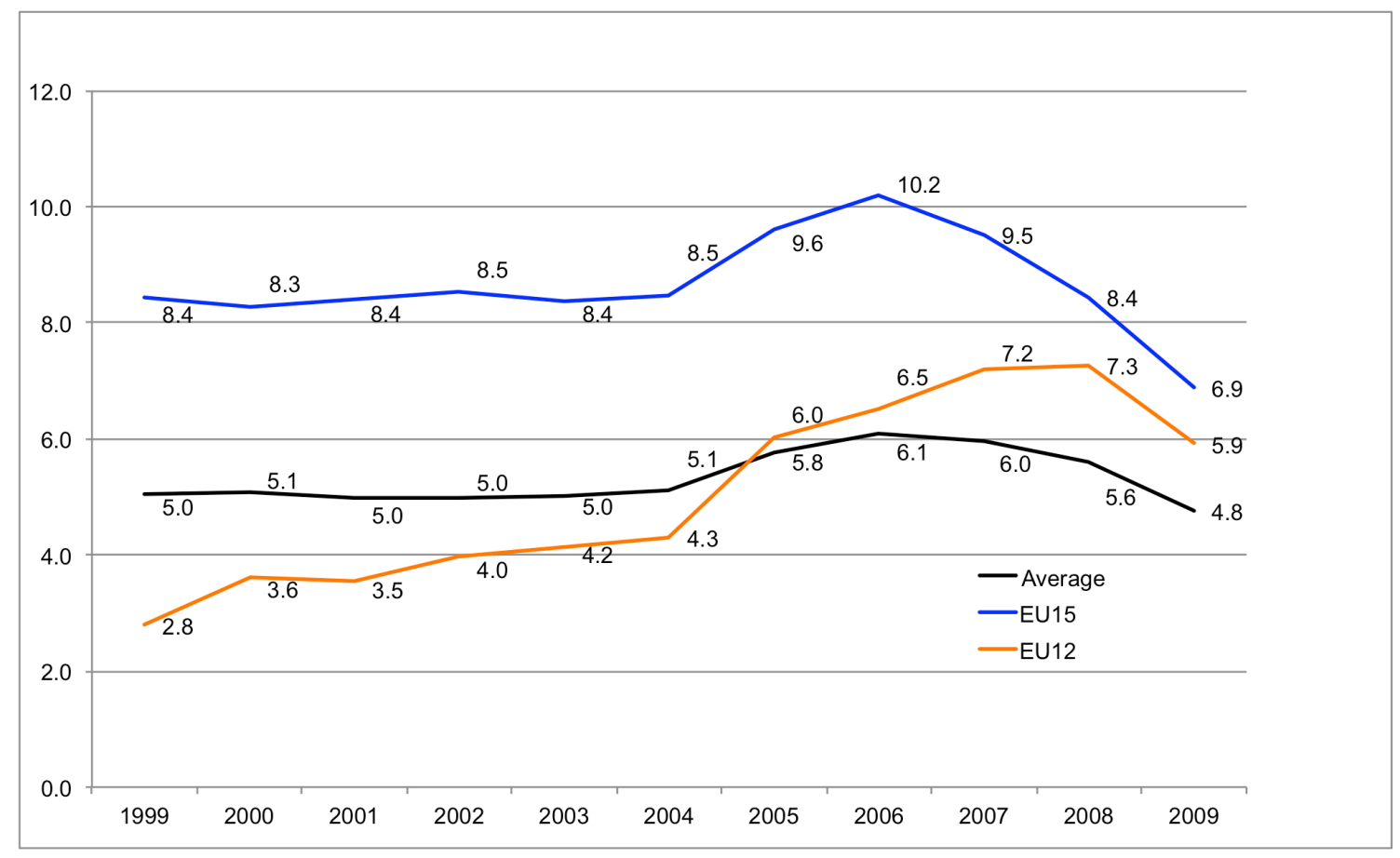

Figure 5: Per capita extraction of construction minerals in tonnes, 1999-2009; own calculations on the basis of British Geological Survey $(2005,2010,2011)$

Accordingly, the index of the per capita extraction of construction minerals shows a consistent progress of EU-15 figures (see Figure 6). It was more less unchanged at 100\% until 2004, rose until 2006 to $121 \%$ and slightly dropped in the last years (82\% in 2009). The index for EU-12 reached a peak in 2008 with $260 \%$ of the 1999 figures and has only dropped in 2009 to $212 \%$. 


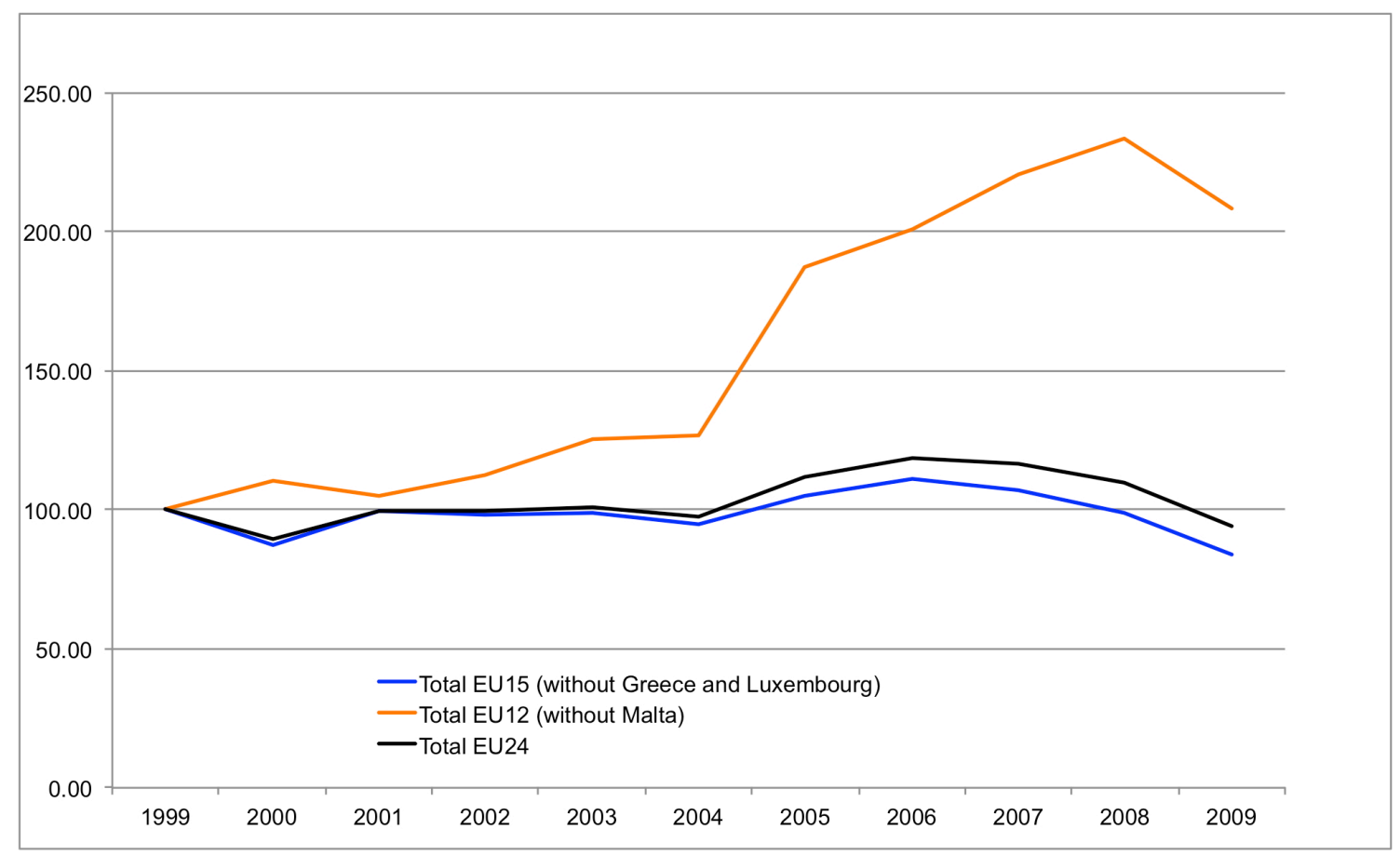

Figure 6: Index of per capita extraction of construction minerals, 1999-2009; own calculations on the basis of British Geological Survey $(2005,2010,2011)$

Considering the analysis above, it is likely that the EU-12 countries are continuing to catch up. This is actually being supported by high EU subsidies from the EU Structural and cohesion funds in order to balance the development gaps in the Central and Eastern European countries. For example, 53\% of the means allocated to the ten CEE countries ${ }^{2}$ within the programming period 2007-2013 are planned for investment in road transport infrastructure, $30 \%$ for railway, equivalent to about 50 billion EUR. The total budget of the EU Structural and cohesion funds plans to allocate altogether $20 \%$ for transport infrastructures that will be construction material intensive (such as airports, ports, railways, motorways) covering more than 68 billion EUR within 2007-2013 (Usubiaga et al. 2011). Correspondingly, Euroconstruct - a large construction business research group - forecasts the "end of downturn in the west, upturn in the east" after three years of recession but a growing "shift from new construction towards renovation and modernisation" in the coming years (Euroconstruct 2010).

\section{Conception of a construction minerals tax}

\subsection{Targets, mechanisms and expected impacts}

The basic idea of a primary construction minerals tax is to increase material efficiency by gradually increasing the price of the raw material and contribute to resource conservation, the reduction of life-cycle wide impacts associated with extraction and use of the materials and stimulate innovation, substitution and recycling efforts. The price signal of a quantity related extraction tax should successively reach the

2 The CEE 10 countries are: Bulgaria, Czech Republic, Estonia, Hungary, Latvia, Lithuania, Poland, Romania, Slovakia, Slovenia 
market players in the construction sector, provided the price increase is passed on. Innovation incentives arise not only for the extracting industry, but also for the production and transport of building materials, and for architects, the construction industry and producers of construction waste. Ideally, reactions take place where the marginal costs are low, i.e. the incentive may affect both the extraction of the resources and the resource efficiency of the processing. Ultimately, the tax can and should also reduce the construction waste deposited in landfills, which is affected by other regulations too.

The assumptions above distinguish a primary construction minerals tax from classical economic assumptions à la Pigou, in which the internalising of the negative external costs is sought (Kosonen and Nicodème 2009). Recent debates emphasise the difficulties of an exact determination of negative external costs and identify the relationship between factor prices and innovation as well as the advantages of economic incentives within a policy mix (Aghion et al. 2009; Bretschger et al. 2010; European Environment Agency 2006; Jackson 2009; Popp 2002, 2009). The argument here accordingly aims at increasing the resource efficiency and innovation in the construction sector; a reduction of the specific environmental impacts can be reached at least in terms of the direction though not quantifiable at present.

A construction minerals tax designed as a quantity tax charging per unit of weight follows the logic that not only extraction but also processing, transportation and use of the raw material are material-intensive and cause external effects, which are at least partially dependent on weight. This "increases the cost of the production of those items which directly and indirectly have a high content of raw materials over all production stages. Thus, at every stage of production there will be an incentive to reduce the materialintensive input. Resource-intensive consumer goods will be substituted by other goods as a result of its rising price" (Meyer 2009: 6; translation by the authors). It is assumed that a change of purchasing price will penetrate the product prices along the value chain. Fixed and predictable price signals are better to plan and thus lower the transaction costs for the actors affected. A tax also has advantages when the precise meeting of targets of a fixed schedule is not required, where, for example, tradable permits would be favourable. The economic incentive of a tax has is an innovation-supporting broad effect towards all market participants without having to determine specific impacts (Aghion et al. 2009; Bretschger et al. 2010; European Environment Agency 2006; Popp 2002, 2009).

Söderholm rightly emphasises the motivation of taxation. Starting from the failure of markets as regards their capability to satisfactorily regulate resource depletion and/or externalities, he analyses the efficiency of resource taxation for different motives. In most cases, for resource depletion, negative externalities at the production processes, negative externalities downstream and encouraging substitution efforts targeted policies that address the relevant market failures "as closely as possible” (Söderholm and Tilton 2012) are the first-best policies. These are, for example, better-defined property rights, pollution, waste or disposal taxes and input taxes, which would be the instruments of choice (Söderholm 2011). The extraction, production and use of construction minerals is faced with a number of environmental impacts and has to be based on different motives that can be addressed with a construction minerals tax, provided it has a tangible and perceptible financial incentive to reduce consumption, strengthen substitution and make production processes more efficient. From an economic perspective, taxes are usually second-best policies due to their inherent impreciseness; from an environmental perspective, taxes are a step towards reflecting the full external and social costs of resource extraction. Ideally, a primary construction minerals tax has to be an integral part of a policy mix and will directly affect the extractive companies and indirectly the subsequent production stages (concrete and cement production) and it works indirectly as an innovation incentive to promote the recycling of construction minerals. In this respect, it has to be stressed that an increase in resource efficiency is highly challenging, not as least as regards policy integration. 


\subsubsection{Increase of input quota of recycling and secondary materials}

Besides a reduction in demand for primary materials technical innovations and material innovations can be expected. ${ }^{3}$ Recycled and secondary minerals resulting from high-quality reprocessing are usually granulates sorted in size by crushing and sieving with a fixed or mobile facility separating unwanted materials such as wood, plastic, metal or paper. The recycled building materials are used in road construction, gardening and landscaping, earthworks (such as noise protection) and increasingly in the production of concrete - albeit at a low level so far and few approaches for a high-quality material flow management (Knappe 2009).

An important regulative incentive to increase the recycling rates of construction and demolition waste is given in the EU Waste Framework Directive (2008/98/EC) determining that "In order (...) to move towards a European recycling society with a high level of resource efficiency, Member States shall take the necessary measures designed to achieve the following targets: (...) by 2020 the preparing for re-use, recycling and other material recovery, including backfilling operations using waste to substitute other materials, of non-hazardous construction and demolition waste excluding naturally occurring material defined in category 170504 in the European Waste Catalogue $(E W C)^{4}$ shall be increased to a minimum of $70 \%$ by weight."

Almost 550 million tonnes of construction minerals were needed for construction in Germany in 2004, the majority are sand, gravel and crushed stone. About 200 million tonnes of mineral construction waste were produced at the same time: $25 \%$ demolition material, $10 \%$ roadway rubble, $1 \%$ mixed C\&D waste corresponding to approximately 72 million tonnes altogether - and 64\% dredging soil (128 million tonnes). The excavated soil is mostly used in road construction, as track ballast or for embankment. About 49.6 million tonnes of the materials needing treatment were recycled. This corresponds to a specific recycling rate of $68.5 \%$. Recycling materials, however, are still mainly used as road base, in civil engineering to backfill road construction, so-called down-cycling (Knappe 2009).

Some studies show surprisingly high recycling rates. It is therefore important to pay attention to the composition of the Construction and Demolition Waste materials referred to and which quota is consequently reported as a recycling quota (Fischer and Werge 2009). Table 2 shows the complicated composition of the total supply of theoretically recyclable and re-usable materials in Germany in 2004, the amount and percentage of their immediate re-use, recycling and land filling (Schaefer and Pahl 2007).

3 The stimulation of secondary markets for recycling products may also require the introduction of supply-side measures due to the low own-price elasticity, as discussed by Blomberg and Söderholm (2009) for the case of secondary aluminium.

$4 \quad$ soil and stones not containing dangerous substances 
Table 2: Reuse and recycling of construction minerals in 2004 in Germany

\begin{tabular}{|l|c|c|c|c|c|c|c|}
\hline Material & $\begin{array}{c}\text { Supply } \\
\text { in mt }\end{array}$ & $\begin{array}{c}\text { Land filling } \\
\text { in mt }\end{array}$ & in \% & $\begin{array}{c}\text { Immediate } \\
\text { reuse in mt }\end{array}$ & in \% & $\begin{array}{c}\text { Recycling } \\
\text { in mt }\end{array}$ & in \% \\
\hline Demolition material & 50.5 & 4.6 & 9.1 & 14.8 & & 31.1 & 61.6 \\
\hline Roadway rubble* & 19.7 & 0.2 & 1.0 & 0.7 & & 18.4 & \\
\hline $\begin{array}{l}\text { Mixed Construction } \\
\text { \& Demolition waste }\end{array}$ & 1.9 & 1.4 & 73.7 & 0.4 & & 0.1 & \\
\hline $\begin{array}{l}\text { Total net C\&D } \\
\text { waste }\end{array}$ & 72.1 & 6.2 & 8.6 & 15.9 & 22.1 & 49.6 & 68.8 \\
\hline $\begin{array}{l}\text { Dredging / excavat- } \\
\text { ed soil }\end{array}$ & 128.3 & 15.7 & 12.2 & 103.5 & & 9.1 & 7.1 \\
\hline Total & 200.4 & 21.9 & 10.9 & 119.4 & 59.6 & 58.7 & 29.3 \\
\hline $\begin{array}{l}\text { Primary construc- } \\
\text { tion minerals }\end{array}$ & 548.5 & & 4.0 & & 21.8 & & 10.7 \\
\hline
\end{tabular}

*Numbers used in the original source do not reach $100 \%$.

Source: Schaefer and Pahl 2007

When these figures are studied in detail, it seems as if the efficient reuse and recycling performance emerges especially in the areas of soil excavation and road construction - due to a high percentage of soil and track ballast in the recycled and reused materials. For the purposes of the Directive, the outcome is a recycling rate of more than $80 \%$. This logic leads to fact that the quantity of the excavated soil can determine the amount of the recycling rates (Fischer and Werge 2009), as long as it is not statistically evaluated how much of this quantity covers non-hazardous and naturally occurring soils and stones as called for in the Waste Framework Directive.

Compared with the volume of waste, the specific recycling rate of materials that need treatment is about $25 \%$ (dredging soil not included). But if the question shall be answered as to how much of the extracted primary construction minerals are de facto replaced by recycled materials, Germany showed a quota of only 11\% in 2004 (Schaefer and Pahl 2007).

In future, it would be useful to focus more strongly on a specific material utilisation rate compared to primary materials. Apart from covering soil and earth, the recycling rate does not consider the increasing amounts of materials stocked in infrastructures and thus hides the future waste. An increase of the recycling and secondary material utilisation rate should contribute to the reduction of the primary construction minerals extraction. A definition of the recycling rate as a percentage of the total demand is also used by European Environment Agency (2008). The low recycling and secondary material utilisation rate in Germany indicates need for action.

Roland Berger (2007) finds the highest growth potential in material efficiency within the environmental technologies; resource-efficient construction materials, recycling and the use of recycled construction materials and resource-efficient construction may well be regarded as a green area of growth (Weizsaecker et al. 2009; Essex and Whelan 2010; and with reference to sustainable settlement structures Bringezu 2009). Future technology is likely to use a growing share of recycled materials. The challenge is that many natural stone products cannot be disaggregated into the single raw material components, as irreversible processes have been accomplished in the production process. Even when a treatment is possible, 
the former quality may often not be achieved. According to Haefner the proportional ratio of material recycling and recycled building materials of the total resource use can achieve at best $20 \%$ (Haefner 2006). However, the estimates vary greatly in this area between 8 and 28\%. Regarding the potential of a high-quality recycling of building waste and a "urban mining", further research is needed. ${ }^{5}$

\subsubsection{Barriers and trade-offs}

The price increase of a resource that is associated with negative externalities leads - through the expected decline in demand - to a lowering of the costs that have to be borne by society, and thus to a more efficient allocation of resources. The mining regions should provide for accompanying measures to cover specific costs and take into account planning instruments and tools (Seht 2010) and / or use of parts of the revenue for compensatory measures. Positive externalities may arise if environmentally friendly products and innovations are encouraged, such as a building grain that has both heat-insulating and soundabsorbing qualities and can be used in concrete. For this reason it is necessary that the secondary or recycled building materials are cheaper than primary construction minerals in the long run. This is where the proposed construction minerals taxation aims for. The general context of factor prices and innovation is now the state of research (Aghion et al. 2009; Bretschger et al. 2010; European Environment Agency 2006; Popp 2002, 2009). It is essential that this instrument achieves innovation effects throughout the value chain and achieves the public debate. In this respect, it also contributes to a reduction of information deficits.

Rebound effects are not expected in the field of primary construction minerals. A rebound effect emerges when savings resulting from more efficient technologies are compensated through increased usage and consumption. However, the efficient use of resources can heat up the consumption spiral (Sorrell 2007). It should be noted though that construction minerals are not continuously consumed products, unlike e.g. electricity and water; there is no apparent incentive for additional consumption of the good by cost savings. A secondary rebound could theoretically arise when financial flexibility stemming from the use of relatively favourable recycled construction minerals would result in larger buildings (Hertwich 2008). Specific measures for an energy- and material-efficient design of buildings could be appropriate.

The signalling effect of decreasing sales of primary materials and rising sales of recycled construction minerals due to the environmental tax (Barigozzi and Villeneuve 2006), fired by a tax increase in the cost of primary materials, should also give incentives in the following production stages of the construction industry to exploit the resources more efficiently and expand the application and use of recycled construction minerals. Especially, the target groups of architects and the construction industry are addressed. In the value chain and material flow system, there is currently only a small incentive to develop resource efficiency potentials.

Sectoral barriers lie in the unclear legal situations with regard to the recovery of construction and demolition wastes and the classification of hazardous and non-hazardous wastes. It is crucial that the regulation is compatible with the level of recycling of C\&D waste or the manufacture and use of RC construction minerals achieved (Dehoust et al. 2008).

5 On the whole, the statistical situation for recycling and secondary materials in the construction area needs improvement. Figures show large differences among the sources. According to Eurostat, the available data for construction waste are generally not comparable, given that there is no statistical reporting at European level in this area. Due to the introduction of mandatory waste management plans in many Member States, it can be assumed that the quality of reporting in this area will improve in the long term. 
As regards institutional barriers, it is important that municipal decision-makers have influence on construction measures in the regional environment. Path dependencies and so-called "institutional resource regimes" (Gerber et al. 2009) may result from planning deficits contributing to increased cement and concrete production and construction and civil engineering.

Possible trade-offs:

Due to many market actors involved in a rather complex supply chain, interests diverge. The taxation of a material flow involves a conflict that the recipient agencies (state, federal) of the tax are more interested in keeping the material flowing than in reducing the material flow (European Commission 2007). At the same time, public construction is a large part of the construction investment made; hence a tax on construction minerals is at risk to be a mere reallocation of funds. Conflicting claims for land use come up in densely populated regions.

The elasticity of demand is another point that should be observed in the context of a construction minerals tax. Unintended effects on trade, tax distortions and ecologically damaging transport increases may result when demand is inelastic and the tax rate is set so high that imports are becoming more attractive. Another point is that the recycling rate is also subject to demolition and deconstruction and the less demolition and deconstruction material is produced through refurbishment programs, the less recycling material is available. Substitutes may need more energy for the mining and processing. This can be the case, for example, with crushed rock compared with gravel. Last but not least, since the individual states have different geologically and topographically conditions, a construction minerals tax may increase competition between the regions concerned (Bahn-Walkowiak et al. 2011).

\subsection{Experiences and diffusion of minerals extraction taxes in Europe}

Practical experiences with the effect of differently designed resource taxes have been collected in some EU countries, e.g. in UK/Northern Ireland, Sweden, Denmark, Lithuania, Latvia, Bulgaria, the Czech Republic, Cyprus and Italy and Belgium on the regional level. In these countries, taxes or charges for sand, gravel and/or further construction minerals are being collected (European Environment Agency 2008). Different designs of the instruments, collection procedures and tax bases (such as extraction volume, market value or land use for the excavation) can have varying resource consumption-lowering and substitution effects. It is also important whether the tax is raised centrally or regionally and who are the beneficiaries of the tax/duty (federal, state or local governments). Table 3 shows that most countries collect taxes at such a low level that resource use lowering effects are rather unlikely. Due to data inconsistencies and gaps, regional taxes/charges are left out in the following. The table refers to the countries with verifiable revenues in the OECD database.

Table 3: Taxes on construction minerals in Europe and tax rates

\begin{tabular}{|l|l|l|r|r|}
\hline Country & \multicolumn{1}{|c|}{$\begin{array}{c}\text { Name of tax, } \\
\text { charge or duty }\end{array}$} & \multicolumn{1}{|c|}{ Taxable object } & $\begin{array}{c}\text { Year of } \\
\text { introduction }\end{array}$ & \multicolumn{1}{|c|}{ Tax rates* } \\
\hline Bulgaria & Mining charge & Sand and gravel & 1997 & $0.03-0.08 €$ per $\mathrm{m}^{3}$ \\
\hline Croatia & Extraction charge & $\begin{array}{l}\text { Sand, gravel, crushed } \\
\text { stone, limestone, } \\
\text { clay }\end{array}$ & $\begin{array}{l}0.41 € \text { per } \mathrm{m}^{3} \text { (sand) } \\
0.55 € \text { per } \mathrm{m}^{3} \text { (gravel) }\end{array}$ \\
\hline Cyprus & Quarrying charge & $\begin{array}{l}\text { Materials extracted } \\
\text { from quarries }\end{array}$ & $\mathrm{Ca} .1998$ & $0.26 €$ per tonne \\
\hline
\end{tabular}




\begin{tabular}{|c|c|c|c|c|}
\hline Country & $\begin{array}{l}\text { Name of tax, } \\
\text { charge or duty }\end{array}$ & Taxable object & $\begin{array}{c}\text { Year of } \\
\text { introduction }\end{array}$ & Tax rates* \\
\hline Czech Republic & $\begin{array}{l}\text { Payments for } \\
\text { mineral extraction }\end{array}$ & Aggregates & 1993 & $\begin{array}{l}\text { up to } 10 \% \text { of the market price } \\
\text { for minerals }\end{array}$ \\
\hline Denmark & $\begin{array}{l}\text { Tax on raw mate- } \\
\text { rials }\end{array}$ & $\begin{array}{l}\text { Stone, sand, gravel, } \\
\text { peat, clay, limestone }\end{array}$ & 1990 & $\begin{array}{l}\approx 0.67 € \text { per }^{3} \text { (since } 1990 \\
\left.\text { fixed at } 5 \mathrm{DKK} \text { per } \mathrm{m}^{3}\right)\end{array}$ \\
\hline Estonia & $\begin{array}{l}\text { Material extrac- } \\
\text { tion charge }\end{array}$ & $\begin{array}{l}\text { Dolomite, granite, } \\
\text { gravel, sand, lime- } \\
\text { stone, clay, peat, } \\
\text { phosphate rock, oil } \\
\text { shale }\end{array}$ & 1991 & $\mathrm{n} / \mathrm{a}$ \\
\hline France & $\begin{array}{l}\text { Tax on extracted } \\
\text { minerals (granu- } \\
\text { lates) }\end{array}$ & Minerals (granulates) & $1999 / 2000$ & $\begin{array}{l}0.09 € \text { per } t \text { (natural mineral } \\
\text { grains; EC database) } \\
0.20 € \text { per } t \text { (extracted miner- } \\
\text { als; OECD database) }\end{array}$ \\
\hline Latvia & $\begin{array}{l}\text { Material extrac- } \\
\text { tion charges }\end{array}$ & $\begin{array}{l}\text { Gravel, limestone, } \\
\text { clay }\end{array}$ & 1991 & $\begin{array}{l}\approx 0.11 € \text { per } \mathrm{m}^{3} \text { (sand) } \\
\approx 0.13 € \text { per } \mathrm{m}^{3} \text { (dolomite) } \\
\approx 0.18 € \text { per } \mathrm{m}^{3} \text { (limestone) } \\
\approx 0.21 € \text { per } \mathrm{m}^{3} \text { (sand-gravel) }\end{array}$ \\
\hline Lithuania & $\begin{array}{l}\text { Mineral extraction } \\
\text { charge }\end{array}$ & Minerals & 1991 & $\begin{array}{l}\left.\approx 0.14 € \text { per }^{3} \text { (sand }\right) \\
\approx 0.17 € \text { per } \mathrm{m}^{3} \text { (gravel) } \\
\approx 0.38 € \text { per } \mathrm{m}^{3} \text { (dolomite) } \\
\approx 0.50 € \text { per } \mathrm{m}^{3} \text { (limestone) }\end{array}$ \\
\hline Sweden & Natural gravel tax & $\begin{array}{l}\text { Gravel, sand, cobble, } \\
\text { boulder }\end{array}$ & 1996 & $\begin{array}{l}1996: \approx 0.57 € \text { per } \mathrm{t} \\
2006: \approx 1.41 € \text { per } \mathrm{t}\end{array}$ \\
\hline United Kingdom & Aggregates levy & $\begin{array}{l}\text { Sand, gravel, crushed } \\
\text { Rock }\end{array}$ & 2002 & $\begin{array}{l}2002: \approx 2.61 € \text { per } \mathrm{t} \\
2010: \approx 2.30 € \text { per } \mathrm{t}\end{array}$ \\
\hline
\end{tabular}

*Note: Conversion factor of sand, gravel, crushed rock $\approx 1.8$ tonne per $\mathrm{m}^{3}$, limestone $\approx 2.8$ tonne per $\mathrm{m}^{3}$

Source: OECD/EEA database on instruments used for environmental policy and natural resources management, OECD/EEA 2011 and own estimations and calculations

As regards the taxation of raw materials, and especially the taxation of primary construction materials, one can speak of a certain degree of international distribution. Hence, raw material taxes are often a proven and reliable source of governmental revenues (Söderholm 2011); many of them at a rather low level. However, whether the taxes are designed as green taxes and serve as an introduction to the rise of factor prices would require a more detailed review (e.g. Meyer and Ludewig 2009).

The gravel tax implemented in Sweden since 1996 is an example of a centralised ad quantum tax on a single raw material. The tax has a geological background and is mainly motivated by the objective to 
preserve ground water reservoirs (Söderholm 2011). The purpose of the tax is thus to replace the gravel with alternative construction materials such as crushed rock, but also recycled and secondary materials (Andersson 2004).

The gravel tax is included in a policy mix. Besides the tax the concession procedures to obtain a gravel pit were tightened and national reduction targets were agreed upon (e.g. a ratio of 30/70 in relation to substitutes and a recycling rate of $15 \%$ ). The tax is applied to both mining and export, but not imports. In 2007 , SEK 13 had to be paid per metric tonne (approximately equivalent to $€ 1.30$ ). Government revenue amounted to approximately SEK 250 million (equivalent to about 25 million $€$ ) in 2006 (Swedish Tax Agency 2007). Approximately 75 million tonnes, which are mined in Sweden each year, the recycling rate is around $11 \%$. Sweden also has an upper extraction limit of 12 million tonnes of gravel for the year 2010 (European Environment Agency 2008).

In Denmark where a raw material tax came into law in 1990 charges, differently from that in Sweden, all domestic extraction and imports of rocks and soils, i.e. gravel, crushed stone, clay, limestone, silica sand, etc. The raw material tax is perceived as an environmental tax on scarce resources, aiming at the substitution and the recycling of materials. From the beginning the tax was fixed at DKK 5.00 (approximately $€ 0.67 / \mathrm{m}^{3}$ ).

Italy is an example of a decentralised ad quantum tax with different tax rates at the regional and local level (between $€ 0.41$ to $0.57 / \mathrm{m}^{3}$ ) in accordance with a national revenue of $€ 110$ million, benefiting the respective administrative units. The specific feature of the tax is unclear, the prices vary between $€ 8$ and $€ 15$ /tonne (European Environment Agency 2008). Theoretically, there is an allocation of funds for mitigation measures in the field of extraction activities. In reality, a use will often be for other purposes. Like Germany Italy is characterised by a complex multi-level design of the field. The recycling rate in Italy is rather low at about $7.5 \%$. The effects of the tax are assessed as limited, as there is a clear preference for new materials in the Italian construction industry (European Environment Agency 2008). To what extent accompanying instruments such as a circular economy law is missing in Italy, leading to a relatively minor effects despite high prices cannot be resolved at this point.

The Aggregates Levy in Great Britain and Northern Ireland (United Kingdom) implemented in 2002 is an example of a centralised ad quantum tax. An extracted tonne comprising sand, gravel and crushed stone were initially taxed at $£ 1.60$. This represented approximately $20 \%$ of the average commodity price and a total of $£ 338$ million of tax revenue (OECD/EEA 2011). Since 2010, the rate is $£ 2.1 /$ tonne (currently equivalent to approximately $€ 2.30$ ). The Aggregates Levy is the only tax among the resource taxes with a notable range.

The aim of the tax which is understood as a "green tax" is to reduce the environmental impacts of extraction and transportation of construction materials including noise, dust, earth tremors, visual landscape alterations, loss of biodiversity, etc., and thus to internalise external costs. Main demand for construction minerals (40\%) in Great Britain and Northern Ireland comes from the public sector for infrastructures and road construction. The collected funds are strictly used for environmental projects in the construction industry and to compensate for regions. The Aggregates Levy Sustainability Fund has ended in March 2011.

The results of this tax are a reduction by about 6 million tonnes (of a total demand of 275 million tonnes) in 2005. 68 million tonnes recycling and secondary materials are used (equivalent to approximately $25 \%$ ). In particular, the recycling market has been strongly boosted, while the reduction of the primary resources decrease remains relatively low. This effect is not only attributed to the aggregate levy, but also to previous measures such as Landfill tax of 1996. In addition, there has been a general decline in road construc- 
tion. Technical improvements in the construction industry that require a low intensity have supported the effect (European Environment Agency 2008).

In summary, it can be stated that, almost without exception, all countries impose very low taxes with probably little or no incentive effect. Only UK has induced a noticeable rise in prices by introduction of the Aggregates Levy and has caused, above all, a boost of the recycling market. It has to be noted though that these figure show sand and gravel only. They do not show limestone.

\section{Case study: A primary construction minerals tax in Germany}

Due to the high importance of the construction sector for the increase of resource efficiency and to the present low rate of recycled construction minerals input in Germany the introduction of a primary construction mineral tax has been proposed (Bahn-Walkowiak et al. 2010). The introduction has to be planned with care and should be linked to other measures. As the very diverge tax systems of the European Member States and the EU principle requires unanimity votes on tax matters, it appears unlikely that a single European construction minerals tax is being introduced in the short term. The development of a minimum tax directive similar to the Energy Tax Directive 2003/96/EC could be an option and has been proposed (Bleischwitz et al. 2009). The design as a tax or charge would then be free to the Member States.

A very important player in the field of construction is the public sector. More than one third of the investments for structural and civil engineering come from the public sector. In 2010,32\% of the turnover came from public non-housing construction, $36 \%$ from private non-housing construction and $32 \%$ from private residential construction. Overall, $10 \%$ of the GDP was used for construction activities (Hauptverband der Deutschen Bauindustrie e.V. 2012). Experiences with the use and the high-quality input of recycled concrete, however, are still few in Germany (Knappe 2011). A voluntary commitment of the sector for the reduction of the use of primary materials has been phased out (Knappe 2009).

In general, the launch of a resource tax has different options: a taxation on land use required for the extraction; the quantity extracted (ad quantum); the value of the sales (ad valorem); the input for use. The tax and charge base can therefore be the quantity in tonnes, the area in square meters, hectares or square kilometres, the product value in Euros or the amount used in tonnes. The proposal developed here refers to two German legal norms, namely the established Federal mineral oil tax and the "Länder" land use charge.

\subsection{Federal excise tax on the extraction and the import of primary construction minerals}

A primary construction minerals tax is a fiscal policy tool. Although the government is gaining revenues, it will give an incentive to reduce the resource consumption, similar to the mineral oil tax. The revenues gained will feed in the federal budget and can be used without earmarking. The taxable entities are the resource extracting and importing companies, which will pass the price, increases resulting from the tax along the value chain onto the end-consumers. The tax should levy at least $€ 2.00$ on each tonne of extracted sand, gravel, crushed stone and limestone. In addition, long-term tax increases of 5\%/ year should be planned to counter the inherent real reduction in the amount of the tax.

Relocations of mining and quarrying enterprises and the downstream stages of production to foreign countries as a result of a primary building mineral tax are not very likely or negligible. This is all the 
more true when a national unification from country- and district-specific regulations is realised. However, an increasing use of recycled and secondary raw materials in the construction industry, inducing innovation processes in favour of high-quality applications can be expected. Relocation operation sites of the sector are also unlikely due to high transport costs. Compensation for the mining areas could be provided in order to internalise environmental costs and develop regional innovation potentials.

\subsection{Reform of the current land use and extraction charge}

The German Mining Law (Bundesberggesetz of 1980) does not address mineral resources such as sand, gravel, and limestone. The extraction of those resources is regulated in specific laws of the individual federal states such as the emissions control law, the excavation laws or the water management law. An expansion of the currently minor land use and extraction charge of the federal states to other resources and its significant increase could therefore be a further option from a long-term sustainability perspective. It would address the scarcity of land and could be re-designed regarding the environmental consequences of land use.

The present taxable base of the charge is the land use in square kilometres, starting at $5 € / \mathrm{km}^{2}$ up to $25 € /$ $\mathrm{km}^{2}$. The tax base of the extraction charge is the market value. The extraction charge amounts to approximately $0.20 € /$ tonne or about $7 \%$ of the market value. Due to the relative insignificance of both charges, they have no verifiable effects in terms of reducing the demand for primary materials or increasing the demand for secondary and recycled materials. Environmental aspects played no role in the 1980 law. The revenue from the charge is added to the tax revenues of the federal state and is therefore relevant to the financial equalisation scheme between the Federal Government and the states.

For the federal level a uniform federal excise tax on the extraction and import of primary materials is proposed. The land use levy could either remain for the time being or advanced with environmental policy targets towards a land use tax. The current tax rates would have to be increased accordingly or modified. In order to achieve a steering effect, the tenfold of today's rates may be required at least. The current extraction charge could - after negotiations with the countries on an appropriate compensation - be omitted. Thus, the tax base is changed from the market value to the quantity. In sum, this would contribute to the harmonisation of the law in Germany. The proposal for a construction minerals tax in Germany is summarised in Table 4.

Table 3: Proposal for a construction minerals tax in Germany

\begin{tabular}{|l|l|l|l|l|}
\hline \multicolumn{1}{|c|}{ Instrument } & \multicolumn{1}{|c|}{ Purpose } & Recipient & \multicolumn{1}{c|}{ Tax payer } & \multicolumn{1}{c|}{ Tax base } \\
\hline Federal excise tax & $\begin{array}{l}\text { Fiscal revenue, } \\
\text { incentive tax }\end{array}$ & $\begin{array}{l}\text { Federal } \\
\text { budget }\end{array}$ & $\begin{array}{l}\text { Resource } \\
\text { extracting } \\
\text { companies }\end{array}$ & $\begin{array}{l}\text { € 2.00 per tonne sand, gravel, } \\
\text { crushed rock, limestone (raw } \\
\text { materials for construction prod- } \\
\text { ucts) } \\
+5 \% \text { increase per year }\end{array}$ \\
\hline Land use charge & $\begin{array}{l}\text { Charge as compen- } \\
\text { sation for granting } \\
\text { rights to exploration } \\
\text { and exploitation of } \\
\text { mineral resources }\end{array}$ & $\begin{array}{l}\text { Federal state } \\
\text { budgets }\end{array}$ & $\begin{array}{l}\text { Resource } \\
\text { extracting } \\
\text { companies }\end{array}$ & $\begin{array}{l}\text { Land use } \\
\text { Presently different but should } \\
\text { be increased significantly. }\end{array}$ \\
\hline
\end{tabular}

The primary construction minerals tax is thus conceived as a quantity tax and the reform of the land use charge would be designed as a future land use tax. The concept is dynamic, as the revenue from the tax - 
unlike the taxes on the factors capital and labour and the factor-neutral taxes, which grow in nominal terms in connection with inflation - would fall off over time at constant tax rates. A quantity tax in general has a dampening effect on world market price fluctuations, but this is irrelevant in construction materials markets.

The introduction of a primary construction minerals tax for Germany is in accordance with a general tendency to tax resource extraction in the Europe and could be an important step towards the reorientation of labour-related taxes towards raw materials. In addition, it would expand the existing basis of energy taxation in Germany. A rough estimation of what a general European construction minerals tax could gain as revenues is shown in Table 5. It compares current and potential revenues on the basis of the database of the OECD/EEA and the tax database of the European Commission. The revenues could be more than tenfold of the present value when the British system of aggregates taxation would be implemented in the whole of Europe.

Table 4: Production of primary construction minerals (sand, gravel, crushed rock) in $2008^{6}$, actual and potential revenues in the EU from a construction minerals taxes; OECD/EEA database 2011, European Commission "Taxes in Europe" database 2011a and own calculations

\begin{tabular}{|c|c|c|c|c|}
\hline Country & $\begin{array}{l}\text { Share of produc- } \\
\text { tion in per cent }\end{array}$ & $\begin{array}{l}\text { Extraction of } \\
\text { aggregates in } \\
\text { million tonnes } \\
\quad 2008\end{array}$ & $\begin{array}{l}\text { Actual revenues } \\
\text { in EUR in } 2008\end{array}$ & $\begin{array}{l}\text { Potential reve- } \\
\text { nues in EUR } \\
(2 \text { EUR/t })\end{array}$ \\
\hline France & 14.7 & 408.4 & $\mathrm{n} / \mathrm{a}$ & 816.8 \\
\hline Germany* & 14.3 & 397.4 & $\mathrm{n} / \mathrm{a}$ & 794.8 \\
\hline Spain & 11.9 & 332.0 & -- & 664.0 \\
\hline Italy* & 9.6 & 266.2 & $\mathrm{n} / \mathrm{a}$ & 532.4 \\
\hline United Kingdom & 7.7 & 213.5 & 452.0 & 427.0 \\
\hline Poland & 6.8 & 188.8 & -- & 377.6 \\
\hline Finland & 4.1 & 113.0 & -- & 226.0 \\
\hline Sweden & 3.1 & 85.6 & 27.0 & 171.2 \\
\hline Greece & 3.1 & 85.0 & -- & 170.0 \\
\hline Ireland & 3.1 & 85.0 & -- & 170.0 \\
\hline Netherlands & 2.4 & 67.6 & -- & 135.2 \\
\hline Portugal & 2.4 & 67.1 & -- & 134.2 \\
\hline Austria & 2.4 & 66.3 & -- & 132.6 \\
\hline Denmark & 2.2 & 60.3 & 27.0 & 120.6 \\
\hline Czech Republic & 1.9 & 54.2 & 26.0 & 108.4 \\
\hline Hungary & 1.9 & 53.7 & -- & 107.4 \\
\hline Belgium & 1.9 & 51.6 & -- & 103.2 \\
\hline Bulgaria & 1.5 & 40.8 & -- & 81.6 \\
\hline Romania & 1.3 & 36.0 & -- & 72.0 \\
\hline Slovenia & 1.2 & 34.2 & -- & 68.4 \\
\hline Slovakia & 0.9 & 23.9 & -- & 47.8 \\
\hline Lithuania & 0.6 & 16.4 & 5.5 & 32.8 \\
\hline
\end{tabular}

$6 \quad$ Without Malta and Luxembourg 


\begin{tabular}{|l|r|r|r|r|}
\hline Country & $\begin{array}{c}\text { Share of produc- } \\
\text { tion in per cent }\end{array}$ & $\begin{array}{c}\text { Extraction of } \\
\text { aggregates in } \\
\text { million tonnes } \\
\mathbf{2 0 0 8}\end{array}$ & $\begin{array}{c}\text { Actual revenues } \\
\text { in EUR in 2008 }\end{array}$ & $\begin{array}{c}\text { Potential reve- } \\
\text { nues in EUR } \\
\text { (2 EUR/t) }\end{array}$ \\
\hline Cyprus & 0.5 & 14.2 & $\mathrm{n} / \mathrm{a}$ & 28.4 \\
\hline Estonia & 0.4 & 11.6 & 18.9 & 23.2 \\
\hline Latvia & 0.4 & 10.3 & 13.5 & 20.6 \\
\hline Total & $\mathbf{1 0 0 . 0}$ & $\mathbf{2 , 7 8 3 . 1}$ & $\mathbf{5 6 9 . 9}$ & $\mathbf{5 , 5 6 6 . 2}$ \\
\hline
\end{tabular}

* Countries have regional taxes but no data provided

\subsection{Results of a simulation study}

In a recent research project ${ }^{7}$ the economic effects of a tax on construction minerals were one of the subjects of simulation studies. ${ }^{8}$ In the simulation it is assumed that in the year 2012 a tax on construction minerals is introduced in Europe with a tax rate of $2 € /$ ton. This rate rises per year by $5 \%$ and reaches $4.80 €$ in the year 2030. The tax has to be paid by the domestic extractor. Since the tax is charged in all European countries, not only the import price for construction minerals, but also all other import prices in the product chain of construction minerals will rise. It is an additional taxation without revenue recycling.

Until the year 2030 the domestic producer price for the sector "mining and quarrying (non-energy)" will rise by $43 \%$. The sales of that branch will diminish in real terms by $16.8 \%$. The most important purchaser of their products is the sector "glass and ceramics", which reduces its inputs of products "(non-energy) mining and quarrying" by 5.5\%. The second important customer, the construction sector, buys $16.5 \%$ less. Both branches raise their prices only marginally ("glass and ceramics": $+1.2 \%$, "construction": $+0.4 \%$ ) so that losses in real sales also are very low ("glass and ceramics": $-0.6 \%$, "construction":-0.3\%). The tax on construction minerals in the first line induces technological change, which raises resource efficiency. Final demand for goods is nearly unaffected. Construction activities are nearly not reduced, but houses are built more resource efficiently.

The macroeconomic effects of the tax in the year 2030 are negligible: the price index of gross production rises only by 0.07 , and the consumer price index is not more than $0.02 \%$ higher than in the baseline. GDP reduces by $0.09 \%$, employment by $0.03 \%$. These very small negative effects would totally diminish or even be changed to positive ones, if the tax revenue is not used for debt reduction as assumed in the simulation experiment.

The effects on resource consumption are strong: total material requirement of Germany totally reduces by $1.5 \%$, and domestic extraction reduces in Germany by $9.7 \%$.

7 Material Efficiency and Resource Conservation (MaRess). For further information on the research activities and results within this framework look at: http://ressourcen.wupperinst.org/en/home/index.html

8 The simulations were carried out with the economic environmental model PANTA RHEI for Germany, which links total material requirement, energy consumption, a traffic module, a dwelling module and a demographic module with the economic development in deep sectoral detail (Distelkamp et al. 2010, pp 30; Meyer et al. 2007). 


\section{Conclusions}

"Improved efficiency of natural resources such as metals and minerals are essential aspects of resource efficiency", the European Commission states (European Commission 2011c, 13) and suggests, inter alia, "a major shift from taxation of labour towards environmental taxation" by 2020 (European Commission $2011 \mathrm{c}, 11$ ). If the goals and recommendations of the 'Roadmap to a Resource Efficient Europe' to promote the development and use of market-based instruments are to be taken seriously, there are a number of arguments in favour of the introduction of a construction minerals tax both at German and EU level. First, the extraction of construction materials does not have the largest environmental impact but it has considerable relevance in relation to material intensity and long-term life-cycle effects. It can expand the hegemonic energy-based taxation, which is a well-established instrument of resource taxation by now (Ekins and Speck 2011). Second, a construction minerals tax can contribute to a decrease in the demand for a further non-renewable resource besides fossil fuels. The potential of recycling and secondary materials is not fully exploited yet; there is need for improvement. Third, from a social sustainability perspective a tax can generate funding for programmes and research while relocation processes, due to very limited cross-border trade of the transport-sensitive material, are rather unlikely as well as strong regressive effects, due to the low prices of the materials per tonne in relation to the price of a complete building. In the short term, it can be assumed that the demand is rather inelastic; in the long term the tax can strongly contribute to resource efficiency by promoting competitiveness in the field of resource-efficient construction. In addition and as encouraged by the European Commission (2011b), resource taxes have the potential to contribute to reductions on labour and other taxes, countervail the prevailing unfavourable economic shortage of labour and be a first step to more comprehensive environmental tax reforms all over Europe.

\section{$5 \quad$ References}

Aghion P, Hemous D, Veugelaers R (2009) No green growth without innovation. Bruegel Policy Brief No. 7, Brussels.

Andersson L (2004) Taxing Raw Materials - A Qualitative Study on the Swedish Tax on Natural Gravel and the Danish Tax on Raw Materials. Lulea University of Technology, Department of Business Adminstration and Social Sciences. Available from: http://epubl.luth.se/1404-5508/2004/028/LTU-SHUEX-04028-SE.pdf. Accessed 7 February 2012.

Bahn-Walkowiak, B, Bleischwitz, R (2011) Einführung einer Primärbaustoffsteuer zur Erhöhung der Ressourceneffizienz im Baubereich, in Hennicke, P, Kristof, K (eds.) Aus weniger mehr machen Strategien für eine nachhaltige Ressourcenpolitik in Deutschland, München, pp 68-78.

Bahn-Walkowiak B, Bleischwitz R, Sanden J (2010) Einführung einer Baustoffsteuer zur Erhöhung der Ressourceneffizienz im Baubereich: Meilenstein zu AS 3.2 „Maßnahmenvorschläge zur Ressourcenpolitik zur Gestaltung der Rahmenbedingungen“; Paper zu Arbeitspaket 3 des Projekts ,Materialeffizienz und Ressourcenschonung“ (MaRess), Wuppertal Institute for Climate, Energy, Environment. Available from: http://ressourcen.wupperinst.org/downloads/MaRess_AP3_7.pdf. Accessed 30 March 2012.

Barigozzi F, Villeneuve B (2006) The signaling effect of tax policy. Journal of Public Economic Theory. 8 (4), pp 611-630. doi: 10.1111/j.1467-9779.2006.00281.x 
Bleischwitz R, Bahn-Walkowiak B (2007) Aggregates and Construction Markets in Europe: Towards a Sectoral Action Plan on Sustainable Resource Management. Minerals \& Energy - Raw Materials Report, 1651-2286, 22 (3/4), pp 159-176. doi: 10.1080/14041040701683664

Bleischwitz R, Giljum S, Kuhndt M, Schmidt-Bleek F et al. (2009) Eco-innovation - Putting the EU on the path to a resource and energy efficient economy. European Parliament, Brussels Available from: http://www.europarl.europa.eu/document/activities/cont/201109/20110906ATT25985/20110906ATT 25985EN.pdf. Accessed 30 March 2012.

Blomberg, J, Söderholm, P (2009) The economics of secondary aluminium supply. An econometric analysis based on European data. Resources, Conservation and Recycling 53 (8), pp 455-463. DOI: 10.1016/j.resconrec.2009.03.001

Bretschger L, Brunnschweiler C, Leinert L, Pittel K, Werner T (2010) Preisentwicklung bei natürlichen Ressourcen. Vergleich von Theorie und Empirie. Unmwelt-Wissen, Nr. 1001. Bundesamt für Umwelt, Bern. Available from: http://www.bafu.admin.ch/publikationen/publikation/01520/index.html?lang=de. Accessed 15 September 2011.

Bringezu, S (2009) Visions of a sustainable resource use. In: Bringezu, S, Bleischwitz, R (eds.) Sustainable Resource Management. Trends, Visions and Policies for Europe and the World. Greenleaf Publisher, Sheffield, UK, pp 155-215.

British Geological Survey (2005) European Minerals Statistics, 1999-2003. Keyworth, Nottingham, UK.

British Geological Survey (2010) European Minerals Statistics, 2004-08. Keyworth, Nottingham, UK.

British Geological Survey (2011) European Minerals Statistic 2005-09. Keyworth, Nottingham, UK.

Bundesberggesetz of 13 August 1980 (BGB1. I S. 1310), last amended by Article 15a of the law on 31 July 2009 (BGB1. I S. 2585).

Bundesanstalt für Geowissenschaften und Rohstoffe (2010) Mineralische Rohstoffe. Available from: http://www.bgr.bund.de/DE/Themen/Min_rohstoffe/min_rohstoffe_node.html. Accessed 22December 2010

Bundesverband Mineralische Rohstoffe e.V. (2009) Allgemeine Information. Available from: http://www.bv-miro.org/index1.html. Accessed 31 January 2011.

Dehoust G, Küppers P, Gebhardt P, Rheinberger U, Hermann A (2008) Aufkommen, Qualität und Verbleib mineralischer Abfälle. Umweltbundesamt, Dessau. Available from: http://www.umweltdaten.de/publikationen/fpdf-1/3706.pdf. Accessed 13 May 2011.

Distelkamp M, Meyer B, Meyer M (2010) Quantitative and qualitative Effects of a forced Resource Efficiency Strategy. Executive Summary. Summary report of Task 5 within the framework of the „Material Efficiency and Resource Conservation“ (MaRess) Project, Wuppertal Institute for Climate, Environment, Energy, Wuppertal. Available from: http://ressourcen.wupperinst.org/downloads/MaRess_AP5_4_ExecSummary.pdf. Accessed 30 March 2012.

Ekins P, Speck S (eds.) (2011) Environmental Tax Reform (ETR). A policy for Green Growth. Oxford University Press, Oxford.

Essex J, Whelan C (2010) Increasing local reuse of building materials. In: Waste and Resource Management - Proceedings of the ICE, 163 (4), pp 183-189. 
Euroconstruct (2010) 2011: End of downturn in the west, upturn in the east. Cautious recovery expected from 2012-2013. Press Info 2-3rd December, 2010. Available from: http://www.euroconstruct.org/pressinfo/pressinfo.php. Accessed 19 May 2011.

European Commission (2011a) "Taxes in Europe" database. Available from: http://ec.europa.eu/taxation customs/taxinv/welcome.do. Accessed 18 May 2011.

European Commission (2011b) A resource-efficient Europe - Flagship initiative under the Europe 2020 Strategy. COM(2011) 21, Brussels.

European Commission (2011c) Roadmap to a Resource Efficient Europe, COM(2011) 571 final, Brussels.

European Commission - Taskforce on Sustainable Construction (2007) Accelerating the development of the sustainable construction market in europe. Report composed in preparation of the Communication "A Lead Market Initiative for Europe" $\{\operatorname{COM}(2007) 860$ final $\}$. Available from: http://ec.europa.eu/enterprise/policies/innovation/policy/lead-marketinitiative/files/construction taskforce report en.pdf Accessed 19 May 2011.

European Environment Agency (2006) Using the market for cost-effective environmental policy: Marketbased instruments in Europe. EEA Technical Report No 1/2006. European Environment Agency, Copenhagen.

European Environment Agency (2008) Effectiveness of environmental taxes and charges for managing sand, gravel and rock extraction in selected EU countries. EEA Report No 2/2008. European Environment Agency, Copenhagen.

European Environment Agency (2010) The European environment - state and outlook 2010 - material resources and waste. European Environment Agency, Copenhagen.

Eurostat (2010) Environmental statistics and accounts in Europe, 2010 edition. Luxembourg.

Eurostat (2011) Environmental tax revenues. URL: http://appsso.eurostat.ec.europa.eu/nui/show.do?dataset=env_ac_tax\&lang=en Assessed 19 May 2011.

Eurostat / European Commission (2010) Taxation trends in the European Union: Data for the EU Member States and Norway, Luxembourg.

EU Waste Framework Directive (2008/98/EC). Available from: http://ec.europa.eu/environment/waste/framework/index .htm. Accessed 6 February 2012.

Federal Environment Agency (2009) Daten zur Umwelt - Umweltzustand in Deutschland: Verwertung von Bauabfällen. Available from; http://www.umweltbundesamt-daten-zurumwelt.de/umweltdaten/public/theme.do?nodeIdent=2311. Accessed 30 November 2010.

Fischer C, Werge M (2009) EU as a Recycling Society: present recycling levels of municipal waste and construction \& demolition waste in the EU. ETC/SCP working paper 2/2009. European Topic Centre on Sustainable Consumption and Production, Copenhagen.

Gerber JD, Knoepfel P, Nahrath S, Varone F (2009) Institutional Resource Regimes: Towards sustainability through the combination of property-rights theory and policy analysis. Ecological Economics Vol. 68, Issue 3, pp 798-809

German Building Materials Association (2008) Gewinnung von Energie- und mineralischen Rohstoffen in Deutschland. Available from: http://www.baustoffindustrie.de/cms/website.php?id=/de/themen/rohstoffe.htm. Accessed 2 May 2012 
Haefner F (2006) Steine-und Erden-Gewinnung in Deutschland: Beitrag zur Rohstoffversorgung oder Auslaufmodell? In: Geoforschungszentrum Potsdam (2006) Innovation und Zukunft der Steine- und Erden-Industrie in Mitteleuropa, Scientific Technical Report STR06/11, Potsdam, pp 28-38. DOI: 10.2312/GFZ.b103-06112

Hauptverband der Deutschen Bauindustrie e.V. (2012) Facts and Charts in English, Berlin. Available from: http://www.bauindustrie.de/zahlen-fakten/statistik/facts-and-charts-english Accessed 22 February 2012.

Hertwich E (2008) Consumption and the Rebound Effect. An Industrial Ecology Perspective. Journal of Industrial Ecology. 9 (1-2), pp 85-98. DOI: 10.1162/1088198054084635

Jackson T (2009) Prosperity without growth? The transition to a sustainable economy. Sustainable Development Commission, London.

Knappe, F (2009) Hochwertiger Einsatz von Recyclingbaustoffen: Hemmnisse, Potenziale, ökologische Bewertung, Presentation at Re-source 2009, Berlin, 23-24 June 2009, Institut für Energie- und Umweltforschung, Heidelberg.

Knappe, F, Lansche, J, Räth, N et al. (2011) Einsatz von Recyclingmaterial aus mineralischen Baustoffen als Zuschlag in der Betonherstellung am Beispiel einer Wohnbebauung an der Rheinallee in Ludwigshafen - Kurzbericht - Forschungsprojekt gefördert durch die Deutsche Bundesstiftung Umwelt AZ 26101 - 23, Heidelberg, Cottbus, Ludwigshafen.

Kosonen K, Nicodème G (2009) The role of fiscal instruments in environmental policy - Taxation papers, Working paper No. 19, 2009. European Union, Luxembourg.

Meyer B (2009) Ressourcenproduktivität und Klimaverträglichkeit. Instrumentenwahl und ihre Wechselwirkungen. gws Discussion Paper 2009/2. Institute for Economic Structures Research, Osnabrück.

Meyer B, Ludewig D (2009) Zuordnung der Steuern und Abgaben auf die Faktoren Arbeit, Kapital, Umwelt. FÖS-Diskussionspapier 2009/01. Green Budget Germany, Berlin.

Meyer B, Distelkamp M, Wolter MI (2007) Material Efficiency and Economic-Environmental Sustainability. Results of Simulations for Germany with the Model PANTA RHEI. Ecological Economics, 63(1), pp 192-200. dOI: 10.1016/j.ecolecon.2006.10.017

Moll S, Watson D (2009) Environmental Pressures from European Consumption and Production - A study in integrated environmental and economic analysis. ETC/SCP working paper 1/2009. European Topic Centre on Sustainable Consumption and Production, Copenhagen. Available from: http://scp.eionet.europa.eu/publications/working\%20paper\%20namea2009/wp/working\%20paper\%20 namea2009. Accessed 22 February 2012

OECD / EEA (2011) Database on instruments used in environmental policy and natural resource management;

tax rates and tax revenues. Available from: http://www2.oecd.org/ecoinst/queries/selcountry.asp?q=81\&qry=Taxbases-Tax\%20Rates and http://www2.oecd.org/ecoinst/queries/selcountry.asp?q=80\&qry=Taxbases-Revenues. Accessed 4 April 2011

Popp D (2002) Induced Innovation and Energy Prices. American Economic Review, 92 (1), pp 160-180.

Popp D (2009) Policies for the development and transfer of eco-innovations. Lessons from the literature. OECD Environment Working Papers No. 10, OECD, Paris.

Roland Berger (2007) Umweltpolitische Innovations- und Wachstumsmärkte aus Sicht der Unternehmen. Forschungsprojekt im Auftrag des Umweltbundesamtes, Reihe "Umwelt, Innovation, Beschäftigung", Band 2/07, Berlin. ISSN: 1865-0538 
Schaefer B, Pahl G (2007) Baustoffrecycling - eine nachhaltige Entscheidung. BKS-Aktuell - Informationen des $B K S$ - Bundesverband der Deutschen Kies- und Sandindustrie e.V., pp 43-45.

Sciullo C, Smihily M (2006) Güterkraftverkehr nach Gütergruppen 1999-2004. Statistik kurz gefasst Verkehr 11/2006. Eurostat, Luxembourg. URL Available from: http://www.edsdestatis.de/de/downloads/sif/nz 06 11.pdf. Accessed 30 March 2012.

Seht H von (2010) Die regionalplanerische Steuerung des Abbaus von nicht-energetischen Bodenschätzen. Raumforsch Raumordn 68, pp 419-431. doi: 10.1007/s13147-010-0056-0

Söderholm P (2011) Taxing Virgin Natural Resources. Lessons from Aggregates Taxation in Europe. Resources, Conservation and Recycling 55 (11), pp 911-922. doi: 10.1016/j.resconrec.2011.05.011

Söderholm, P, Tilton, J E (2012) Material efficiency: An economic perspective. Resources, Conservation and Recycling 61 (April 2012) pp 75-82. doi:10.1016/j.resconrec.2012.01.003

Sorell S (2007) The Rebound Effect. An assessment of the evidence for economy-wide energy savings from improved energy efficiency. UK Energy Research Centre, London. ISBN 1-903144-0-35

Swedish Tax Agency (2007) Facts about Swedish Excise Duties. Ludvika, SE.

UEPG (2011) A Sustainable Industry for a Sustainable Europe. Annual Review 2009 - 2010. Brussels.

UNEP (2010) Assessing the Environmental Impacts of Consumption and Production. Priority Products and Materials, A Report of the Working Group on the Environmental Impacts of Products and Materials to the International Panel for Sustainable Resource Management. Hertwich, E., van der Voet, E., Suh, S., Tukker, A, Huijbregts M., Kazmierczyk, P., Lenzen, M., McNeely, J., Moriguchi, Y. United Nations Environment Programme, Division of Technology Industry and Economics, Paris, France.

Usubiaga A, Schepelmann P, Bahn-Walkowiak B, Altmann M, Landgrebe R, Piotrowski R (2011) EU subsidies for polluting and unsustainable practices; Study for the Directorate General for Internal Policies, Policy Department A: Economic and Scientific Policy, Environment, Public Health and Food Safety. European Parliament, Brussels. Available from: http://www.europarl.europa.eu/activities/committees/studies/download.do?language=en\&file=34691. Accessed 21 March 2011.

Weizsaecker E-U von, Hargroves KC, Smith M, Desha C, Stasinopoulos P (2009) Factor Five. Transforming the global economy through $80 \%$ improvements in resource productivity. Earthscan Publisher, London.

WRAP [Waste and Resources Action Programme] (2011) WRAP Aggregates Programme. URL: http://www.wrap.org.uk/downloads/WRAP_Aggregates_Programme_2_.9a8f3bda.4078.pdf Assessed 31 January 2011. 